\title{
First report of Staphylococcus isolates identified by genomic analysis from rhizospheric soils of Capsicum annuum L. cv Piquillo
}

\author{
Cristian Daniel Asmat Ortega* ${ }^{\mathbb{D}}$; Bryan Pierre Cruz-Valderrama Sánchez ${ }^{\mathbb{D}}$; \\ Mercedes Elizabeth Chaman Medina (D) \\ Laboratorio de Fisiología Vegetal. Universidad Nacional de Trujillo, Av. Juan Pablo I/ s/n. Ciudad Universitaria, Trujillo,
} Peru.

Received April 3, 2020. Accepted May 15, 2020.

\begin{abstract}
The genus Staphylococcus comprises many species which can be isolated from many sources and could display plant growth-promoting properties. Moreover, Capsicum species are important export crops in Peru, which have gained greater interest in recent years. Therefore, the objective of this research was to identify Staphylococcus isolates from rhizospheric soil samples of $C$. annuum cv. Piquillo in La Libertad, Peru. Bacterial isolates were identified by genomic analysis targeting the 16s rRNA gene. Bacteria were isolated from samples by serial dilutions and cultured in solid medium agar plates. Then, genomic DNA extraction from pure and morphologically distinct isolates, 16s rRNA gene amplification, sequencing and bioinformatic analysis were performed. We found four bacterial isolates from the genus Staphylococcus not previously reported in C. annuum rhizospheric soils: Isolate $\mathrm{Ca} 2$ and $\mathrm{Ca} 5$ which both match to Staphylococcus sp., isolate $\mathrm{Ca} 6$ to Staphylococcus arlettae and isolate Ca7 to Staphylococcus xylosus. Further studies to assess these isolates' impact on crops as well as their potential applications in other fields of research such as antimicrobial development, food processing and pesticide biodegradation are recommended.
\end{abstract}

Keywords: Staphylococcus; 16s rRNA gene; Capsicum annuum L.; rhizospheric soils.

\section{Introduction}

The genus Staphylococcus currently comprises more than 80 species and subspecies according to the website of the List of Prokaryotic names with Standing in Nomenclature by Leibniz Institute DSMZ-German Collection of Microorganisms and Cell Cultures $\mathrm{GmbH}$ (https://lpsn.dsmz.de/genus/staphylococcus, consulted on March of 2020). Bacteria belonging to this genus are generally Grampositive, nonmotile, aerobes, catalasepositive, oxidase-negative and able to grow between 18 and $40{ }^{\circ} \mathrm{C}$ (Oh et al., 2019; Schleifer and Bell, 2015). Regarding the phylogeny, the genus Staphylococcus belongs to the Staphylococcaceae family and the Bacillales order, which shares with species of different genera such as Bacillus, Listeria, Paenibacillus as well as
Macrococcus, Enterococcus, Streptococcus, and Lactobacillus all as part of the phylum Firmicutes (De Vos, 2015; Schleifer and Bell, 2015).

Besides the importance of Staphylococcus as a pathogenic agent of humans and several animals species, from fish to cattle, they could also act as infective agents of plants under certain conditions as described in Arabidopsis thaliana (Canovas et al., 2016; Oh et al., 2019; Prithiviraj et al., 2005). Moreover, apart from the conventional sources of staphylococci mainly recovered from clinical samples extracted from human and animal skin, glands, and mucous membranes, staphylococci can be isolated from diverse sources such as air, water and soil (Correia et al., 2019; Kozajda et al., 2019; Mandal et al., 2015; Schleifer and Bell, 2015).

Asmat, C.D.; Cruz-Valderrama, B.P.; Chaman, M.E 2020. First report of Staphylococcus isolates identified by genomic analysis from rhizospheric soils of Capsicum annuum L. cv Piquillo. Scientia Agropecuaria 11(2): 237-240. 
The importance of staphylococci go beyond their role as pathogens due to their capacity to produce antimicrobial peptides (Bastos et al., 2009), their role in meat fermentation processes (Stavropoulou et al., 2018) and mainly because of the beneficial effects on plants of some strains that inhabit the rhizosphere, as described for mangrove trees and Leptochloa fusca (Holguin, 1992; Shahid et al., 2019). These strains could be considered as rhizobacteria owning attributes related to plant growth promotion such as the capacity to fix nitrogen as well as to produce phytohormones and specific compounds (Holguin, 1992; Shahid et al., 2019). Capsicum annum L. is an important crop in Peru. Members of the genus Capsicum belong to the Solanaceae family and are native of subtropical and tropical areas in America (Tripodi and Kumar, 2019). The cultivar Piquillo is one of five domesticated crops of $C$. annuum which is widely cultivated and studied along with its two variants: hot pepper as a spice crop and sweet pepper as a vegetable crop (Jindal et al., 2020; Khoury et al., 2020). C. annuum cv. Piquillo is an important export crop in Peru which sends this commodity as raw material and other derivate products to the European and American market (Agraria.pe, 2019; MINAGRI and Prolnversion, n.d.). In recent years, along with the promulgation of the Plan of sustainable development of species of the Capsicum genus 2018-2028: peppers and chilies, devised by The Ministry of Agriculture of Peru, greater interest has been taken into this crop (MINAGRI, 2017). Therefore, the objective of this research was to identify Staphylococcus isolates from rhizospheric soil samples of $C$. annuum cv. Piquillo.

\section{Materials and methods}

Bacteria were isolated from rhizospheric soil samples of cultivated Capsicum annuum L. Cv Piquillo areas under open-field conditions in January 2018 in Viru, La Libertad, Peru (08 $24^{\prime} 18^{\prime \prime}$ S, 78 ${ }^{\circ} 51^{\prime} 18^{\prime \prime}$ W). Samples were collected and kept under refrigeration during transportation to the laboratory and stored at $4{ }^{\circ} \mathrm{C}$. Then, morphologically distinct bacteria were isolated by serial dilutions and cultured in Tryptic soy agar (TSA) and Reasoner's 2A (R2A) agar plates at $28^{\circ} \mathrm{C}$ for up to five days. Isolates were labeled as $\mathrm{Ca} 2, \mathrm{Ca} 5, \mathrm{Ca} 6$ and Ca7. After, bacterial genomic DNA extraction from each pure isolate, 16s rRNA gene amplification, sequencing and bioinformatic analysis were performed according to the protocol described by
Belgini et al., 2014. Briefly, genomic DNA was extracted following the CTAB method and DNA integrity and concentration were estimated through electrophoresis in $0.8 \%$ agarose gel stained with SYBR Safe $10.000 \mathrm{x}$ in DMSO (Invitrogen). DNA obtained was used in polymerase chain reaction (PCR) reactions for amplification of 16S IRNA using the primers 10f (5'GAGTTTGATTCAGGCCCTG-3') and 1100r (5'-GTTGTGAGGGTTGGGG-3'). PCR products were purified using mini-columns (GFX PCR DNA and Gel Band Purification Kit, GE Healthcare) and subjected to sequencing in an automated sequencer $A B I$ 3500XL Applied Biosystems ${ }^{\mathrm{TM}}$. Partial 16S rRNA consensus sequences were obtained using the BIOEDIT software (Hall, 1999) and were compared with those of reference type strains available in EZBioCloud (https://www.ezbiocloud.net/) and RDP (Ribosomal Database Project, Wisconsin, USA https://rdp.cme.msu.edu/) databases. The sequences were aligned using the CLUSTAL $X$ program (Thompson et al., 1997) and analyzed with MEGA 7 software (Kumar et al., 2016). The evolutionary distances were calculated using the Kimura DNA substitution model (Kimura, 1980) and the phylogenetic reconstruction was done using the neighbor joining (NJ) algorithm (Saitou and Nei, 1987), with bootstrap values calculated from 1,000 replicates.

\section{Results and discussion}

We identified four bacterial isolates from the genus Staphylococcus not previously reported in $C$. annuum rhizospheric soils: Isolate $\mathrm{Ca} 2$ and $\mathrm{Ca} 5$ which both match to Staphylococcus sp., isolate $\mathrm{Ca} 6$ to Staphylococcus arlettae and isolate $\mathrm{Ca} 7$ to Staphylococcus xylosus.

The presence of Staphylococcus in rhizospheric soils could be explained as bacteria from that genus have been described as ubiquitous, being isolated from many sources such as beach sand, sea water, fresh water, plant surfaces and products, feeds, meat and poultry, dairy products, dust, air and soil (Schleifer and Bell, 2015). Nonetheless, studies reporting Staphylococcus present in rhizospheric soils are still scarce. López et al. (2009) found a mangrove rhizosphere-associated Staphylococcus sp., Leiva et al. (2013) reported a phosphate-solubilizing $\boldsymbol{S}$. vitulinus present in the rhizosphere of cacao, and Shahid et al. (2019) identified two Staphylococcus strains which promoted the growth of maize under salt stress. 
Table 1

Morphological description and molecular identification of Staphylococcus isolates from rhizospheric soil samples of $C$. annuum cv Piquillo. Cell and colony morphology of each isolate are described. Closest GenBank (www.ncbi.nlm.nih.gov/) match's accession number and similarity percentage are shown. +ve. Gram-variable

\begin{tabular}{cccccc}
\hline Isolate & $\begin{array}{c}\text { Cell } \\
\text { morphology }\end{array}$ & Colony morphology & $\begin{array}{c}\text { Closest GenBank } \\
\text { match }\end{array}$ & $\begin{array}{c}\text { Similarity } \\
(\%)\end{array}$ & Molecular ID \\
\hline Ca2 & $\begin{array}{c}\text { Gram-positive } \\
\text { cocci. +ve }\end{array}$ & $\begin{array}{c}\text { Whitish, even surface } \\
\text { and circular regular } \\
\text { edges. }\end{array}$ & AY953148 & 99.76 & $\begin{array}{c}\text { Staphylococcus } \\
\text { sp. }\end{array}$ \\
\hline $\mathrm{Ca} 5$ & $\begin{array}{c}\text { Gram-positive } \\
\text { cocci }\end{array}$ & $\begin{array}{c}\text { Whitish, even surface } \\
\text { and circular regular } \\
\text { edges. }\end{array}$ & AY953148 & 99.85 & $\begin{array}{c}\text { Staphylococcus } \\
\text { sp. }\end{array}$ \\
$\mathrm{Ca} 6$ & $\begin{array}{c}\text { Gram-positive } \\
\text { cocci. +ve }\end{array}$ & $\begin{array}{c}\text { Translucent and shiny, } \\
\text { even surface and } \\
\text { curved regular edges. }\end{array}$ & AB009933.1 & 100 & $\begin{array}{c}\text { Staphylococcus } \\
\text { arlettae }\end{array}$ \\
$\mathrm{Ca} 7$ & $\begin{array}{c}\text { Gram-positive } \\
\text { cocci }\end{array}$ & $\begin{array}{c}\text { Cream-colored, even } \\
\text { surface and circular } \\
\text { regular edges. }\end{array}$ & MRZO01000018 & 99.73 & $\begin{array}{c}\text { Staphylococcus } \\
\text { xylosus }\end{array}$ \\
\hline
\end{tabular}

Regarding $S$. arlettae and S.xylosus, the former has been isolated from poultry and goats, but has also been reported in cardamom rhizosphere as a bacteria with bioremediation potential to degrade fipronil residues (At et al., 2019; Schleifer and Bell, 2015); the latter, is able to grow in habitats that contain only an inorganic nitrogen source and thus could be more free-living than other staphylococci; besides, it has been isolated from beach sand, natural waters, marsh grass, and plant products, and has also been found in the rhizosphere of potato (Berg et al., 2005; Schleifer and Bell, 2015).

Studies concerning rhizospheric microbiome profiling, isolation and identification of rhizobacteria from $C$. annuum report bacteria mainly from Gammaproteobacteria and Bacilliclasses, Serratia and Bacillus genera (Asaff-torres et al., 2017; González et al., 2017). Particularly, S. aureus has been reported in the rhizosphere of cultivated $C$. chinense (Chinakwe et al., 2019). Despite the above, we have not found reports of Staphylococcus present in rhizospheric soils of $C$. annuum. The isolates found in the present research could have the potential to promote plant growth or to be utilized for ecological, industrial and agricultural purposes, therefore, further studies to assess their role in the rhizosphere and their effect on Capsicum and other crops are suggested.

\section{Conclusions}

Not previously reported Staphylococcus sp., Staphylococcus arlettae and Staphylococcus xylosus isolates from $C$. annuum rhizospheric soils were identified. These isolates could have potential applications in agriculture. Further studies to determine their ecological role in the rhizosphere as well as their potential applications in antimicrobial development focusing on antimicrobial peptide production, food processing regarding meat fermentation processes and pesticide biodegradation as reported for fipronil residues in soils are recommended.

\section{Acknowledgments}

We thank Dr. Icela Rogríguez of The National University of Trujillo for her support in the bacterial isolation and Dr. Valeria Maia and her team of the State University of Campinas for their support in the molecular identification.

\section{ORCID}

C.D. Asmat (D) https://orcid.org/0000-0002-2607-8012

B.P. Cruz-Valderrama (D) https://orcid.org/0000-0001-5375-914X M.E. Chaman (D) https://orcid.org/0000-0001-8621-375X

\section{References}

Agraria.pe. 2019. Se debe aprovechar atributos únicos de ajíes peruanos. Available in:

https://agraria.pe/noticias/se-debe-aprovecharatributos-unicos-de-ajies-peruanos-20128

Asaff-torres, A.; Armendáriz-ruiz, M.; Kirchmayr, M.; et al. 2017. Rhizospheric Microbiome Profiling of Capsicum annuum L. Cultivated in Transcribed Spacer 2 rRNA Amplicon. Genome Announcements 5(30): e00626-17.

At, K.; Karthikeyan, S.; Thanga, S. 2019. Occurrence and microbial degradation of fipronil residues in tropical highland rhizosphere soils of Kerala, India. Soil and Sediment Contamination: An International Journal 28(4): 360-379.

Bastos, M.; Ceotto, H.; Coelho, M.; et al. 2009 Staphylococcal Antimicrobial Peptides: Relevant Properties and Potential Biotechnological Applications. Current Pharmaceutical Biotechnology 10(1): 38-61.

Belgini, D.; Dias, R.; Siqueira, V.; et al. 2014. Culturable bacterial diversity from a feed water of a reverse osmosis system, evaluation of biofilm formation and biocontrol using phages. World Journal of Microbiology and Biotechnology 30(10): 2689-2700.

Berg, G.; Eberl, L.; Hartmann, A. 2005. The rhizosphere as a reservoir for opportunistic human pathogenic bacteria. Environmental Microbiology 7(11): 16731685.

Canovas, J.; Baldry, M.; Bojer, M.S.; et al. Cross-Talk between Staphylococcus aureus and Other Staphylococcal Species via the agr Quorum Sensing System. Front Microbiol. 7: 1733.

Chinakwe, E.; Nwogwugwu, N.; Ibekwe, V.; et al. 2019. Isolation and Evaluation of Bacteria Exhibiting 
Multiple Plant Growth Traits in the Rhizosphere of Yellow Bell Pepper (Capsicum chinense). Journal of Advances in Microbiology 14(4):1-6.

Correia, S.; Silva, V.; García-Díez, J.; et al. 2019. One Health Approach Reveals the Absence of MethicillinResistant Staphylococcus aureus in Autochthonous Cattle and Their Environments. Frontiers in Microbiology 10: 2735

De Vos, P. 2015. Bacillales. In: Bergey's Manual of Systematics of Archaea and Bacteria. John Wiley \& Sons, Inc. Belgium. Pp. 1-1.

González, A.; Almaraz, J.; Ferrera, R.; et al. 2017. Caracterización y selección de rizobacterias promotoras de crecimiento en plántulas de chile poblano (Capsicum annuum L.). Revista Internacional de Contaminacion Ambiental 33(3): 463-474.

Hall, T. 1999. BioEdit: A User-Friendly Biological Sequence Alignment Editor and Analysis Program for Windows 95/98/NT. Nucleic Acids Symposium Series 41: 95-98.

Holguin, G. 1992. Two new nitrogen-fixing bacteria from the rhizosphere of mangrove trees: Their isolation, identification and in vitro interaction with rhizosphere Staphylococcus sp. FEMS Microbiology Letters 101(3): 207-216.

Jindal, S.; Dhaliwal, M.; Meena, O. 2020. Molecular advancements in male sterility systems of Capsicum: A review. Plant Breeding 139(1): 42-64.

Khoury, C.; Carver, D.; Barchenger, D.; et al. 2020. Modelled distributions and conservation status of the wild relatives of chile peppers (Capsicum L.). Diversity and Distributions 26(2): 209-225.

Kimura, M. 1980. A simple method for estimating evolutionary rates of base substitutions through comparative studies of nucleotide sequences. Journal of Molecular Evolution 16(2): 111-120.

Kozajda, A.; Jeżak, K.; Kapsa, A. 2019. Airborne Staphylococcus aureus in different environments - a review. Environmental Science and Pollution Research 26(34): 34741-34753.

Kumar, S.; Stecher, G.; Tamura, K. 2016. MEGA7: Molecular Evolutionary Genetics Analysis Version 7.0 for Bigger Datasets. Molecular Biology and Evolution 33(7): 1870-1874.

Leiva, E.; Osorio, M.; Ramírez, R. 2013. Microorganismos asociados a la rizósfera de $\mathrm{C}$ cacao (Theobroma cacao L.) en condiciones de Bosque húmedo Premontano (Bh-PM). Suelos Ecuatoriales 43(1): 35 45.

López, Á.; Castellanos, M.; Pitre, L. 2009. Caracterización bacteriana de la rizósfera del suelo asociado al manglar del delta del Río Ranchería, Riohacha, La Guajira. Suelos Ecuatoriales 39(1): 40-44.
Mandal, S.; Ghosh, A.; Pati, B. 2015. Dissemination of antibiotic resistance in methicillin-resistant Staphylococcus aureus and vancomycin-resistant S aureus strains isolated from hospital effluents. American Journal of Infection Control, 43(12), e87e88.

MINAGRI-Ministerio de Agricultura y Riego. 2017. Plan de Desarrollo de las Especies del género del Género Capsicum 2018-2028. Available in: https://www.minagri.gob.pe/portal/download/pdf/ma rcolegal/normaslegales/resolucionesministeriales/2 017/octubre/rm434-2017-minagri.pdf

MINAGRI-Ministerio de Agricultura y Riego; ProInversión. n.d. Pimiento piquillo. Available at: https://www.minagri.gob.pe/portal/download/pdf/he rramientas/organizaciones/dgca/pimientopiquillo.pdf

Oh, W.; Jun, J.; Giri, S.; et al. 2019. Staphylococcus xylosus infection in rainbow trout (Oncorhynchus mykiss) as a primary pathogenic cause of eye protrusion and mortality. Microorganisms 7(9): 330.

Prithiviraj, B.; Bais, H.P.; Weir, T.; et al. 2005. Down Regulation of Virulence Factors of Pseudomonas aeruginosa by Salicylic Acid Attenuates Its Virulence on Arabidopsis thaliana and Caenorhabditis elegans. Infection and Immunity 5319-5328.

Saitou, N.; Nei, M. 1987. The neighbor-joining method: a new method for reconstructing phylogenetic trees. Molecular Biology and Evolution 4(4): 406-425.

Schleifer, K.; Bell, J. 2015. Staphylococcus. In: Bergey's Manual of Systematics of Archaea and Bacteria. John Wiley \& Sons, Inc. Germany. Pp. 1-43.

Shahid, M.; Ahmed, T.; Noman, M.; et al. 2019. Nonpathogenic Staphylococcus strains augmented the maize growth through oxidative stress management and nutrient supply under induced salt stress. Annals of Microbiology 69(7): 727-739.

Stavropoulou, D.; De Maere, H.; Berardo, A.; et al. 2018. Pervasiveness of Staphylococcus carnosus over Staphylococcus xylosus is affected by the level of acidification within a conventional meat starter culture set-up. International Journal of Food Microbiology 274: 60-66.

Thompson, J.; Gibson, T.; Plewniak, F.; et al. 1997. The CLUSTAL $X$ windows interface: flexible strategies for multiple sequence alignment aided by quality analysis tools. Nucleic Acids Research 25(24): 4876 4882.

Tripodi, P.; Kumar, S. 2019. The Capsicum Crop: An Introduction. In: The Capsicum Genome. Springer, Cham. Switzerland. Pp. 1-8. 